\title{
Improvement of Colloidal Stability in Colloidal Processing for Highly Translucent, Nanosized Zirconia
}

(Peningkatan Kestabilan Koloid dalam Pemprosesan Koloid bagi Zirkonia Berkelutcahayaan Tinggi, Bersaiz Nano)

\author{
Chuin Hao Chin, Andanastuti MuCHTAR*, CHe Husna AZHari, \\ MASFUEH RAZALI \& MOHAMED ABORAS
}

\begin{abstract}
This study aimed to improve the colloidal stability of yttria-stabilized tetragonal zirconia polycrystalline (Y-TZP) suspension through colloidal processing to obtain highly translucent Y-TZP. Agglomeration is often the main complication in the processing of nanosized Y-TZP as it deteriorates mechanical and optical properties. Thus, colloidal processing is necessary to mitigate the agglomeration in Y-TZP. The colloidal stability of Y-TZP suspension plays a key role for the success of colloidal processing. In this study, colloidal processing was conducted at several stages, namely, dispersant addition, $p H$ adjustment and sedimentation. Changes in particle size and zeta potential at various stages were recorded. The suspensions were then slip-casted to form green bodies. Green bodies were sintered and characterized for density and translucency. The results showed that dispersant addition followed by $\mathrm{pH}$ adjustment effectively dispersed soft agglomerates by introducing electrosteric stabilization, whereas sedimentation successfully segregated hard agglomerates and contributed excellent colloidal stability. With high colloidal stability, the translucency of Y-TZP was improved by approximately $30 \%$. This study demonstrated different colloidal processing stages and proved that high colloidal stability and fine particle size are vital to produce highly translucent Y-TZP.
\end{abstract}

Keywords: Colloidal stability; slip casting; translucency; zirconia

ABSTRAK

Kajian ini bertujuan meningkatkan kestabilan koloid polihablur zirkonia tetragonal separa stabil oleh yttria (Y-TZP) melalui pemprosesan berkoloid untuk menghasilkan Y-TZP berkelutcahayaan tinggi. Pengaglomeratan merupakan satu masalah dalam pemprosesan Y-TZP bersaiz nano kerana pengaglomeratan sentiasa menjejaskan ciri mekanik dan optik. Justeru, pemprosesan berkoloid diperlukan untuk mengurangkan pengaglomeratan dalam Y-TZP. Kestabilan koloid ampaian Y-TZP telah memainkan peranan yang penting dalam menjayakan pemprosesan berkoloid. Dalam kajian ini, pemprosesan berkoloid telah dijalankan melalui beberapa peringkat iaitu penambahan bahan penyerak, pelarasan $\mathrm{pH}$ dan pemendapan. Perubahan dalam saiz zarah dan keupayaan zeta pada tahap yang berbeza telah dicatat. Ampaian Y-TZP telah diguna untuk menghasilkan jasad anum melalui kaedah tuangan slip. Jasad anum telah disinter dan seterusnya ketumpatan dan kelutcahayaan spesimen diuji. Keputusan uji kaji menunjukkan aglomerat lembut telah berjaya dipisah melalui penstabilan elektrosterik dengan penambahan bahan penyerak dan pelarasan pH. Proses pemendapan yang seterusnya berjaya memisahkan aglomerat keras dan meningkatkan kestabilan koloid. Dengan kestabilan koloid yang baik, kelutcahayaan Y-TZP telah ditingkatkan sebanyak 30\%. Kajian ini telah menunjukkan peringkat pemprosesan berkoloid yang berbeza dan membuktikan kestabilan koloid yang tinggi dan saiz zarah yang kecil adalah penting untuk penghasilan Y-TZP berkelutcahayaan tinggi.

Kata kunci: Kelutcahayaan; kestabilan koloid; tuangan slip; zirkonia

\section{INTRODUCTION}

Ceramic-based dental crowns have become popular given their outstanding performance in aesthetic restoration compared with metal alloy-based crowns. Yttria-stabilized tetragonal zirconia polycrystalline (Y-TZP) is a ceramic with excellent mechanical properties, such as a superior fracture toughness of approximately $10 \mathrm{MPa} \cdot \mathrm{m}^{1 / 2}$. The desirable mechanical properties of Y-TZP are associated with the toughening mechanism of stress-induced tetragonal zirconia transformation (Ozturk et al. 2008; Stawarczyk et al. 2012). Y-TZP is extensively applied as a dental restoration material because of its mechanical strength, biocompatibility and optical properties that match those of the human tooth (Zhang et al. 2012). Nonetheless, Y-TZP does not meet the aesthetic requirement of dental prostheses because of its inadequate translucency (Baldissara et al. 2010). Kelly et al. (1996) remarked that substructure translucency in a dental crown is the main factor that controls its aesthetic value. Insufficient Y-TZP translucency is a major concern in dental application because it causes the unacceptable aesthetic value of restoration (Sulaiman et al. 2015; Tong et al. 2016). 
Nanosized ceramic powders have received attention because of their more desirable mechanical properties than micron-sized ceramic powders. However, fine ceramic particles with high specific surface areas tend to form soft agglomerates (Rami et al. 2009; Zakaria et al. 2014). Agglomeration is more pronounced with nanoscale particles because of the strong van der Waals force between fine particles. Hard agglomerates or aggregates are formed during the early processing of raw materials, such as during calcination. Strong bridges between particles are formed in hard agglomerates and are more difficult to disperse, unlike soft agglomerates that are held together by weak van der Waals forces. Agglomerates or aggregates cause heterogeneous particle packing in compact powders, which eventually causes undesired characteristics of sintered products, such as high porosity, exaggerated grain growth and cracks. These defects degrade the final mechanical and optical properties of Y-TZP. Therefore, agglomeration in fine powders must be alleviated to produce Y-TZP with good mechanical and optical properties.

Among the many ceramic processing methods, colloidal processing can control the agglomeration and particle size of powders (Amat et al. 2014; Rafferty et al. 2009). In colloidal processing, agglomerated particles are dispersed by manipulating interparticle forces via the following three mechanisms: electrostatic, steric and electrosteric stabilization (Lewis 2000; Rami et al. 2009). Colloidal processing has been widely applied in recent studies to disperse Y-TZP nanoparticles. For example, Trunec and Pouchly (2016) successfully dispersed Y-TZP nanoparticles via colloidal processing, followed by osmotic dehydration, thus producing a compact and fine microstructure in the specimens from the dispersed powder after sintering. Amat et al. (2014) and Chin et al. (2015) electrosterically stabilized a Y-TZP suspension by adding a polyelectrolyte, obtaining a stable Y-TZP suspension. Both studies achieved excellent mechanical properties and desired microstructure in the Y-TZP specimens. Convincing findings from the previous studies were a major motivation in this study to improve the translucency of Y-TZP by colloidal processing because the optical properties of Y-TZP are correlated with its microstructure (Jiang et al. 2011).

This study aimed to improve the colloidal stability of Y-TZP suspension through colloidal processing to enhance Y-TZP translucency. Furthermore, the effects of changes in particle size and distribution on Y-TZP translucency were also investigated. The findings from this study will provide an understanding of correlation between colloidal stability, particle size and distribution and translucency of Y-TZP, which will be helpful to produce Y-TZP with increased translucency for dental applications.

\section{MATERIALS AND METHODS}

\section{MATERIALS}

This study used 3Y-TZP nanopowder (US Research Nanomaterials Inc., Houston, USA), with a BET surface area of $30 \mathrm{~m}^{2} / \mathrm{g}$. The as-received powder was characterized via transmission electron microscopy (TEM), which showed that the primary particle size of the powder was approximately $20 \mathrm{~nm}$ (Figure 1) and that the particles were agglomerated. Polyethyleneimine (PEI, SigmaAldrich, St. Louis, MO, USA) with an average molecular size of 50,000 was used as a dispersing agent during colloidal processing.

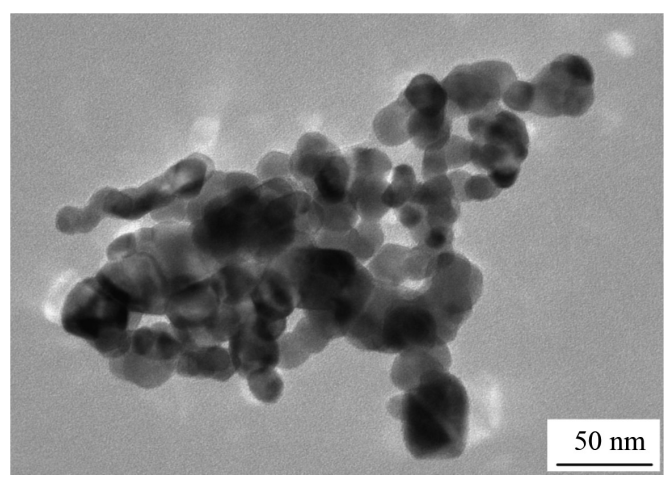

FIGURE 1. TEM image of the as-received Y-TZP powder

\section{COLLOIDAL PROCESSING}

Y-TZP suspension was prepared with a powder loading of $30 \mathrm{wt} . \%$ and distilled water as the dispersing medium. Colloidal processing was conducted in three stages, including PEI addition, $\mathrm{pH}$ adjustment and sedimentation. First, approximately 0.4 wt. \% 0.005 $\mathrm{M}$ PEI was thoroughly mixed into the suspension. The $\mathrm{pH}$ of the Y-TZP suspension was then adjusted to $\mathrm{pH} 2$ with $\mathrm{HNO}_{3}$ solution. The PEI amount and $\mathrm{pH}$ value in this study were optimized based on the results of a previous study (Chin et al. 2015). The suspension was thoroughly stirred with a magnetic stirrer for $45 \mathrm{~min}$ and then placed in an ultrasonic bath for 15 min to break soft agglomerates. Finally, sedimentation was performed to prepare a suspension with limited agglomeration, which was allowed to stand in a long test tube for $24 \mathrm{~h}$. During the sedimentation, the suspension must remain stationary to prevent any interruption and the test tube was sealed with a stopper to prevent vaporization. The supernatant, which consisted of fine particles, was collected. Hard agglomerates were removed by discarding the lower phase, including the sediment.

\section{PARTICLE SIZE AND ZETA POTENTIAL ANALYSIS}

The colloidal stability of the Y-TZP suspensions was characterized based on their particle size and zeta potential, which were monitored at all three colloidal processing stages. Laser light scattering technique was performed using a Zetasizer (Nano ZS, Malvern Instruments, Westborough, MA, USA) to determine the particle size and zeta potential of the Y-TZP suspensions. Measurements were conducted using a Y-TZP suspension diluted to $0.01 \mathrm{vol} . \%$ with distilled water. 


\section{SLIP CASTING AND SINTERING}

Y-TZP suspensions at different stages of colloidal processing were poured in a $15 \mathrm{~mm}$-diameter Teflon mold in a plaster of Paris block and then dried at room temperature for $24 \mathrm{~h}$. The obtained dried green compacts underwent a two-step sintering method. The temperature was increased to $600^{\circ} \mathrm{C}$ at a rate of $3^{\circ} \mathrm{C} / \mathrm{min}$, held at $600^{\circ} \mathrm{C}$ for $45 \mathrm{~min}$, allowed to increase to $1600^{\circ} \mathrm{C}$ at the same rate and held at $1600^{\circ} \mathrm{C}$ for $2 \mathrm{~h}$. The temperature was then gradually lowered to room temperature at a rate of $5^{\circ} \mathrm{C} / \mathrm{min}$.

\section{SAMPLE CHARACTERIZATION}

The sintered density of each Y-TZP sample was measured using a density meter (Newclassic MS, Mettler Toledo, Columbus, OH, USA) and the averaged values are presented in this work. The morphological properties of the Y-TZP samples were studied by field-emission scanning electron microscopy (FESEM, Hitachi SU8000, Hitachi, Tokyo, Japan). Surface preparation was necessary prior to the FESEM. The samples were ground using silicon carbide paper (600, 800 and 1200 grit) and then polished using a diamond suspension ( 3 and $1 \mu$ grit sizes). The samples were thermally etched at $1200^{\circ} \mathrm{C}$ with a heating rate of $20^{\circ} \mathrm{C} / \mathrm{min}$ prior to FESEM to improve the visibility of grain boundaries. Average grain size was measured from the microstructures of each sample using an image analysis software, ImageJ (National Institute of Health, Maryland, USA). At least 200 measurements were conducted on the microstructures of each Y-TZP sample to obtain the average grain size. In this study, Y-TZP translucency was represented by light transmission. The thickness of the Y-TZP specimen was maintained at $0.5 \pm 0.05 \mathrm{~mm}$ with a diamond grinder. Thickness was measured using a vernier calliper with an accuracy of up to $0.01 \mathrm{~mm}$. Light transmission was measured with a spectrophotometer (Lambda 950, PerkinElmer, USA) and an integrating sphere $(60 \mathrm{~mm}$, Int. Sphere, PerkinElmer, USA). The working wavelength ranged from 400 to $700 \mathrm{~nm}$ of the visible light spectrum. Light transmission was measured per $2 \mathrm{~nm}$ interval.

\section{RESULTS AND DISCUSSION}

\section{COLLOIDAL STABILITY OF Y-TZP SUSPENSION}

The various stages of colloidal processing were investigated to determine the changes in the particle size distribution and zeta potential of Y-TZP particles. Figures 2 and 3 depict the particle size distributions and changes in the zeta potentials of the Y-TZP suspensions at different stages of colloidal processing, respectively.

As shown in Figure 2, the peak at $1000 \mathrm{~nm}$ indicated that significant agglomeration occurred during the first stage of colloidal processing, which was after PEI addition. The suspension system was very unstable, as evidenced by the low zeta potential $(16.7 \mathrm{mV})$ shown in Figure 3 . In this study, PEI, a polyelectrolyte, was utilized as a dispersant. Therefore, adding PEI should improve particle dispersion. The addition of PEI, however, changed the surface chemical properties of the Y-TZP particles, thus causing flocculation. Chin et al. (2015) reported that the isoelectric point of Y-TZP before and after the addition of PEI is pH5.5 and pH10.5, respectively. The isoelectric point shifted because PEI is a cationic polyelectrolyte. The $\mathrm{pH}$ of the Y-TZP suspension before $\mathrm{pH}$ adjustment was $\mathrm{pH} 10$. Therefore, after PEI addition, the suspension $\mathrm{pH}$ ( $\mathrm{pH} 10)$ immediately approached a new isoelectric point (pH10.5). Based on DLVO theory, the electrical double layer disappears at the isoelectric point because of the zero net charge at the particle surface, weakening the repulsive electrostatic force between particles and causing pronounced agglomeration. The suspension system became very unstable when the absolute value of the zeta potential was low $(16 \mathrm{mV})$ after PEI addition. Given that adding PEI to the Y-TZP suspension may cause Y-TZP particles to flocculate if the suspension $\mathrm{pH}$ is not carefully adjusted, the solution $\mathrm{pH}$ must be adjusted to the acidic region before PEI addition to prevent the suspension $\mathrm{pH}$ from approaching the isoelectric point.

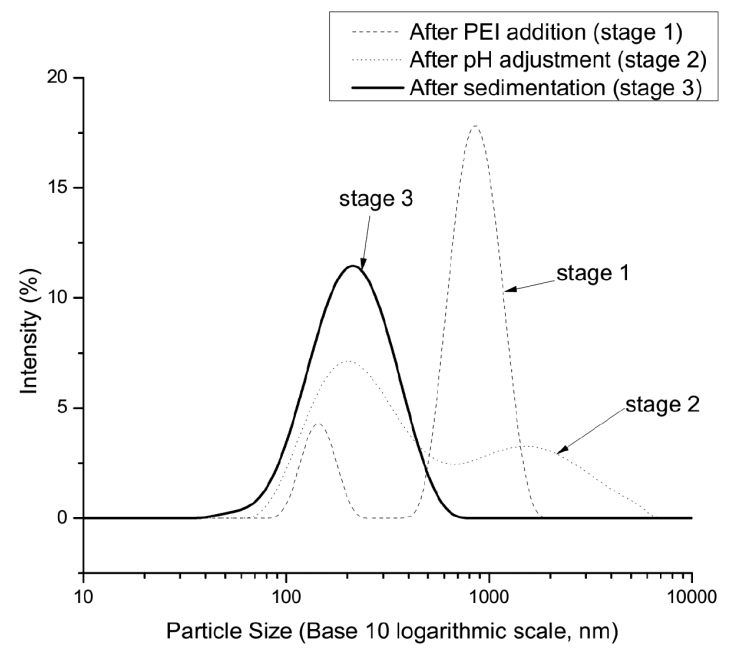

FIGURE 2. Particle size distribution of Y-TZP

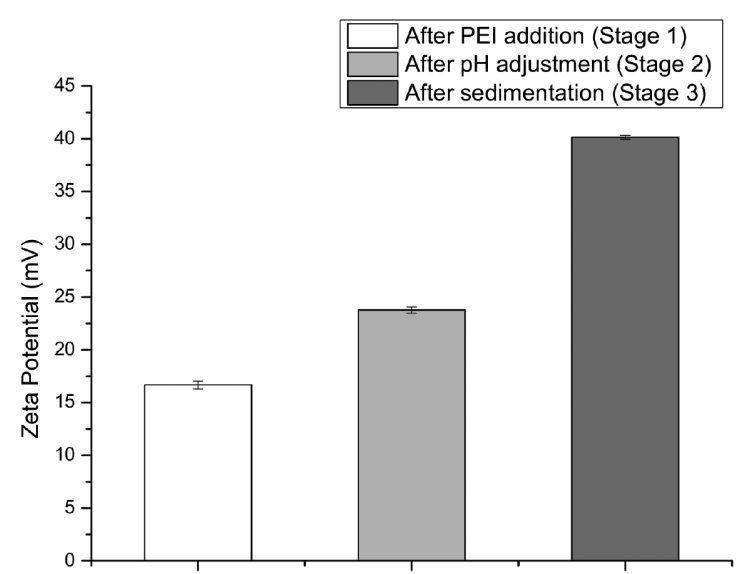

FIGURE 3. Zeta potential of Y-TZP particles at different stages of colloidal processing 
As colloidal processing continued after the suspension $\mathrm{pH}$ was adjusted to $\mathrm{pH} 2$ (stage 2), the agglomerates in the Y-TZP suspension dispersed into smaller sizes, resulting in a wide particle size distribution of 70-7000 nm. However, particle size was still bimodally distributed into two populations of 200 and $1000 \mathrm{~nm}$. The agglomerates dissociated after $\mathrm{pH}$ adjustment because electrical double layers developed around particle surfaces as the suspension $\mathrm{pH}$ shifted away from the isoelectric point ( $\mathrm{pH} 10.5)$. Hence, this dissociation restored the strong repulsive force on particle surfaces to overcome attractive van der Waals force and maintain dispersal. Dissociation also increased the zeta potential of Y-TZP particles from stage 1 to stage 2 (Figure 3), indicating a more stable suspension after $\mathrm{pH}$ adjustment.

PEI addition and $\mathrm{pH}$ adjustment were expected to produce an agglomerate-free Y-TZP suspension. However, the particle size analysis of Y-TZP in Figure 2 shows that some agglomerates persisted even after $\mathrm{pH}$ adjustment. The remaining agglomerates were strongly bound hard aggregates, which were difficult to disperse via colloidal processing and could only be eliminated via sedimentation. During sedimentation, the heavy, large agglomerates settled at the bottom of the vessel faster due to strong gravitational pull compared with the dispersed, fine particles, which remained afloat in the dispersing medium. This mechanism allows large agglomerates to segregate from fine particles in a simple, elegant and inexpensive process and produces a suspension with excellent colloidal stability.

After sedimentation, the particle size distribution of the Y-TZP particles was narrowed to $30-800 \mathrm{~nm}$ with an average particle size of $200 \mathrm{~nm}$. The particle size distribution graph exhibited only one peak at $200 \mathrm{~nm}$ (black, bolded solid line in Figure 2) following sedimentation, which indicated that all large agglomerates with particle sizes larger than $1 \mu \mathrm{m}$ were successfully segregated from the suspension system. In addition, sedimentation significantly influenced the colloidal stability of the Y-TZP sample. The zeta potential of the Y-TZP suspension nearly doubled from 24 to 40 $\mathrm{mV}$ after sedimentation (Figure 3), indicating excellent particle dispersion in the suspension. The zeta potential of Y-TZP suspension after sedimentation is comparable to some previous studies (Liu \& Gao 2003; Xie et al. 2004) which also reported highly dispersed Y-TZP suspensions with zeta potentials between $40-45 \mathrm{mV}$. The absence of large agglomerates in the suspension increased the zeta potential of Y-TZP after sedimentation. Consequently, a highly stable suspension system with well-dispersed, fine particles was obtained.

\section{SINTERED DENSITY}

The sintered densities of the Y-TZP samples are illustrated in Figure 4. No significant difference was observed in the sintered densities of Y-TZP between stages 1 and 2 of colloidal processing. Relative density fluctuated between $91 \%$ and $93 \%$, indicating that the first two colloidal processing stages did not significantly influence Y-TZP density. However, the relative Y-TZP density significantly improved to $99.5 \%$ after the third colloidal processing stage (sedimentation), indicating that Y-TZP achieved full densification after sedimentation.

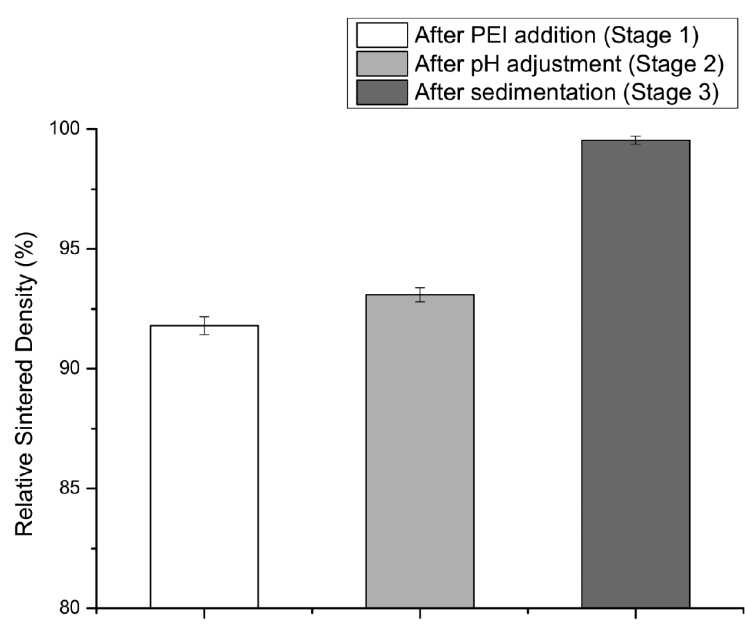

FIGURE 4. Sintered densities of Y-TZP samples

Low density in ceramics is often attributed to microstructure porosity. In Y-TZP colloidal processing, porosity in microstructure is controlled by eliminating agglomeration because agglomerates in suspension cause the inhomogeneous densification of grains during sintering and result in pore or crack formation. Jiang et al. (2011) reported that the higher specific surface area and shorter diffusion path of smaller particles compared with those of larger particles facilitate particle diffusion during sintering. The high specific surface area of fine particles increases driving force and reduces the required activation energy for particle diffusion during sintering (Groza 1999). Therefore, full grain densification can be achieved more easily. Particle size analysis confirmed that before sedimentation, the Y-TZP suspensions contained different amounts of large agglomerates and aggregates, which decreased the densities of the Y-TZP samples during stages 1 and 2 of colloidal processing. In addition, the narrow particle size distribution of the Y-TZP suspension after sedimentation also facilitated densification. Several studies (Ma \& Lim 2002; Ting \& Lin 1995) reported that a broad size distribution results in a high sintering rate but low densification rate after grain growth. This finding arises from different densification rates within agglomerates (intra-agglomerate) and between agglomerates (inter-agglomerate) (Bowen et al. 2005). The narrow particle size distribution of Y-TZP particles after sedimentation enabled the uniform packing of Y-TZP particles for increased homogeneous densification. Hence, removing aggregates narrowed particle size distribution and decreased particle size, which in turn improved particle packing behavior and reduced intraagglomerate densification. 


\section{MORPHOLOGICAL ANALYSIS}

Morphological analysis was conducted to characterize the microstructural properties of Y-TZP specimens. Figure 5 shows the FESEM results for the Y-TZP samples. Consistent with the density analysis results, the microstructures of the Y-TZP samples at stages 1 and 2 of colloidal processing were evidently porous, whereas those after sedimentation (stage 3) were more compact and poreless. Limiting the porosity improves the mechanical properties of compact microstructures. Pores promote crack propagation by acting as stress concentrators (Amat et al. 2014; Kim et al. 2013; Wollmershauser et al. 2014) and are thus responsible for the deterioration of mechanical properties and the early failure of a ceramic body.

The Y-TZP specimens in stages 1,2 , and 3 have average grain sizes of 581,486 and $476 \mathrm{~nm}$, respectively. Increased average grain size in specimens from stages 1 and 2 was attributed to excessive grain growth during sintering, resulting in the presence of some coarse grains with size exceeding $1 \mu \mathrm{m}$. Coarse grains are very unfavorable to the mechanical strength of Y-TZP as they promote crack formation in the ceramic microstructure (Kim et al. 2013; Leong et al. 2017; Stawarczyk et al. 2012). Muchtar and Lim (1998) also explained that fractures occur at the grain boundary in structures that contain fine grains with submicron sizes. This fracture mode is known as intergranular fracture. Another fracture mode is transgranular cleavage, in which fractures propagate across the grain. Fractures in large grains consist of transgranular and intergranular cleavages. Considering the possibility of transgranular fracture decrease as grain size decreases, a ceramic body exhibits increased resistance to transgranular cleavage at a sufficiently fine grain size, thus improving strength. As shown in Figure 5, microstructures obtained from stage 3 demonstrated the most favorable features with fine grains and limited porosity.

The large grains in the stages 1 and 2 Y-TZP samples were mainly caused by large agglomerates in green bodies. These agglomerates caused inhomogeneous grain densification rates because intra-agglomerate densification was more likely to occur than interagglomerate densification. Moreover, differential grain densification during sintering also increases the probability of pore formation. Under different densification rates, an individual grain tends to pull away from its neighboring grains and leaves large voids that are difficult to close. Morphological analysis showed the presence of this phenomenon in the microstructures of the stages 1 and 2 Y-TZP samples (Figure 5(a) and 5(b)). By contrast, the stage 3 sample did not contain agglomerates and exhibited a highly compact and homogeneous microstructure.

\section{LIGHT TRANSMISSION}

The light transmission of Y-TZP samples is shown in Figure 6 . The light transmission test was only conducted in stages 2 and 3 samples because light transmission highly depends on density and porosity (Jiang et al. 2011). The density test and morphological analysis proved that stages 2 and 3 samples exhibited the highest density and lowest porosity.

The stage 3 Y-TZP sample achieved 35\% light transmission. By contrast, the stage 2 Y-TZP sample exhibited a relatively low light transmission of 5\%. This considerable difference in light transmission is closely related to the high tendency of agglomerates to form pores and flaws in the Y-TZP microstructure. The agglomerates formed large open pores in the Y-TZP microstructure because of intra-agglomerate sintering. These pores caused evident light scattering in Y-TZP, which was responsible for
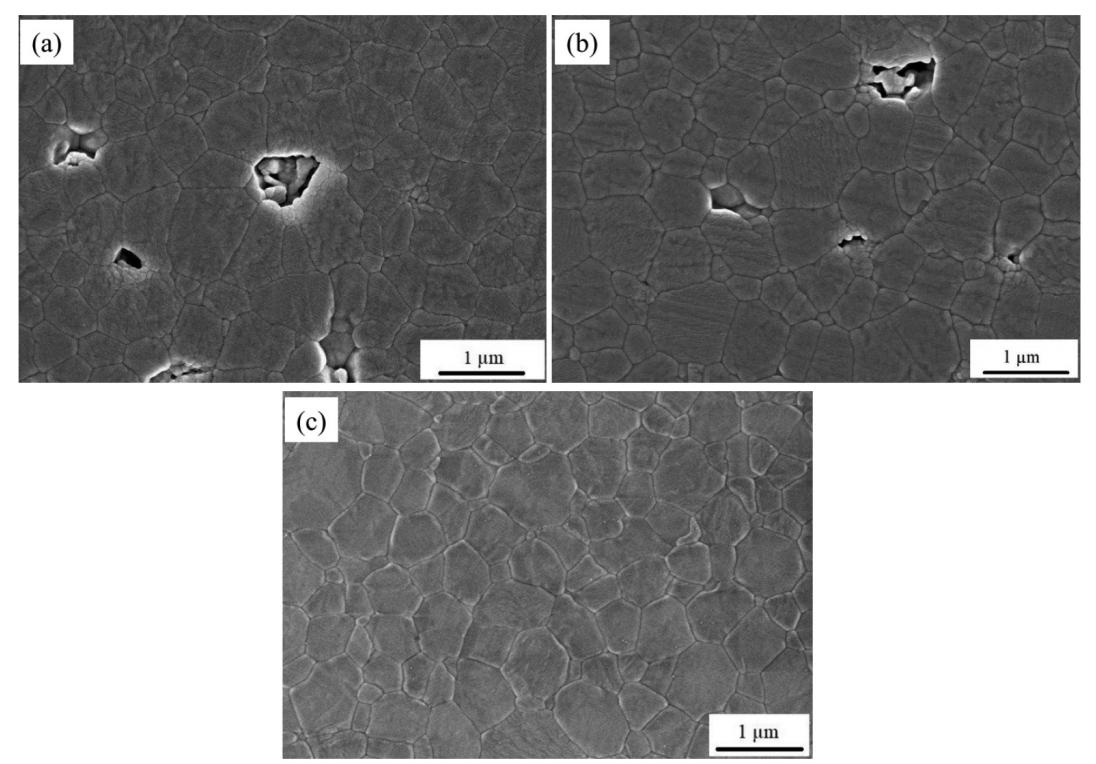

FIGURE 5. Microstructure of Y-TZP samples: (a) after PEI addition (stage 1),

(b) after $\mathrm{pH}$ adjustment (stage 2) and (c) after sedimentation (stage 3 ) 


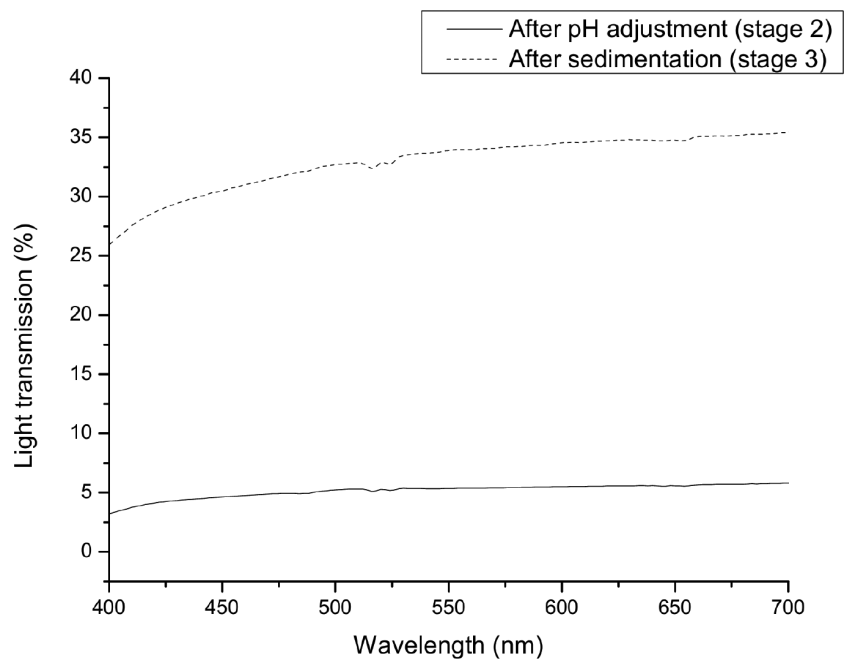

FIGURE 6. Light transmission of Y-TZP specimens

low translucency. Many studies (Jiang et al. 2011; Zhang 2014) reported that in Y-TZP, pores are highly efficient light scattering centers owing to the large difference between the light refractive indices of pore (1.00) and Y-TZP (approximately 2.20). Therefore, high porosity in the microstructure causes significant light scattering and subsequently results in low translucency. In summary, agglomeration deteriorates the mechanical properties of Y-TZP and decreases its translucency. Hence, controlling particle size by eliminating agglomerates during ceramic processing is crucial to produce Y-TZP with excellent mechanical and optical properties.

A very limited number of studies have characterized Y-TZP translucency using light transmission, whereas several (Chen et al. 2008; Heffernan et al. 2002) analyzed Y-TZP translucency based on contrast ratio. The authors of these studies indicated that a contrast ratio of 1 represents complete opacity. Jiang et al. (2011) evaluated Y-TZP translucency using the light transmission method, which is similar to that used in the present study. They utilized cold isostatic pressing (CIP) to fabricate a Y-TZP specimen with a high density of $99.4 \%$ and a light transmission of $18 \%$ at a thickness of $0.5 \mathrm{~mm}$. However, the light transmissions of the CIP samples in the previous study were lower compared with the $35 \%$ light transmission reported in the present study. This disparity occurred because the CIP method did not eliminate agglomerates from the Y-TZP powder. By contrast, the present study utilized colloidal processing and sedimentation to effectively eliminate agglomeration from the Y-TZP powder. The results proved that agglomeration heavily influences the translucency of Y-TZP samples, even those with high density. Therefore, agglomerate removal is recommended to produce highly translucent Y-TZP.

\section{CONCLUSION}

In this study, the following three stages of colloidal processing were demonstrated: PEI addition, $\mathrm{pH}$ adjustment, and sedimentation. The results proved that colloidal stability of Y-TZP suspension is highly related to its translucency. Combining electrosteric stabilization with sedimentation produces Y-TZP suspension with high colloidal stability. PEI addition and $\mathrm{pH}$ adjustment can break soft agglomerates, whereas sedimentation effectively segregates hard agglomerates from the as-prepared suspension. Thus, a Y-TZP suspension with highly dispersed particles was obtained. The high colloidal stability of the Y-TZP suspension led to a high translucency (35\% of light transmission) in the sintered Y-TZP, increasing the suitability of this material for dental applications. In this study, both particle size and distribution are crucial in the Y-TZP sintering process. Small particle sizes and narrow size distribution allowed for a uniform grain densification process, producing a homogeneous, compact and fine microstructure necessary for excellent mechanical property and translucency.

\section{ACKNOWLEDGEMENTS}

This work was financially supported by Universiti Kebangsaan Malaysia (UKM) and the Ministry of Education, Malaysia through a research sponsorship with Grant No. DIP-2016-001. The authors also acknowledge the support of the Centre for Research and Instrumentation Management, UKM, as well as Hi-Tech Instrument Sdn. Bhd. for their excellent testing equipment.

\section{REFERENCES}

Amat, N.F., Muchtar, A., Ghazali, M.J. \& Yahaya, N. 2014. Suspension stability and sintering influence on yttriastabilized zirconia fabricated by colloidal processing. Ceramics International 40(4): 5413-5419.

Baldissara, P., Llukacej,A., Ciocca, L., Valandro, F.L. \& Scotti, R. 2010. Translucency of zirconia copings made with different cad/cam systems. The Journal of Prosthetic Dentistry 104(1): 6-12.

Bowen, P., Carry, C., Luxembourg, D. \& Hofmann, H. 2005. Colloidal processing and sintering of nanosized transition aluminas. Powder Technology 157(1-3): 100-107. 
Chen, Y.M., Smales, R.J., Yip, K.H.K. \& Sung, W.J. 2008. Translucency and biaxial flexural strength of four ceramic core materials. Dental Materials 24(11): 1506-1511.

Chin, C.H., Muchtar, A., Azhari, C.H., Razali, M. \& Aboras, M. 2015. Optimization of $\mathrm{pH}$ and dispersant amount of Y-TZP suspension for colloidal stability. Ceramics International 41(8): 9939-9946.

Groza, J.R. 1999. Nanosintering. Nanostructured Materials 12(5-8): 987-992.

Heffernan, M.J., Aquilino, S.A., Diaz-Arnold, A.M., Haselton, D.R., Stanford, C.M. \& Vargas, M.A. 2002. Relative translucency of six all-ceramic systems. Part I: Core materials. The Journal of Prosthetic Dentistry 88(1): 4-9.

Jiang, L., Liao, Y., Wan, Q. \& Li, W. 2011. Effects of sintering temperature and particle size on the translucency of zirconium dioxide dental ceramic. Journal of Materials Science: Materials in Medicine 22(11): 2429-2435.

Kelly, J.R., Nishimura, I. \& Campbell, S.D. 1996. Ceramics in dentistry: Historical roots and current perspectives. The Journal of Prosthetic Dentistry 75(1): 18-32.

Kim, M.J., Ahn, J.S., Kim, J.H., Kim, H.Y. \& Kim, W.C. 2013. Effects of the sintering conditions of dental zirconia ceramics on the grain size and translucency. Journal of Advanced Prosthodontics 5(2): 161-166.

Leong, C.H., Muchtar, A., Tan, C.Y., Razali, M. \& Chin, C.H. 2017. Sintering of hydroxyapatite under nitrogen atmosphere for improved microhardness. Sains Malaysiana 46(9): 16351640 .

Lewis, J.A. 2000. Colloidal processing of ceramics. Journal of the American Ceramic Society 83(10): 2341-2359.

Liu, Y. \& Gao, L. 2003. Deflocculation study of aqueous nanosized Y-TZP suspensions. Materials Chemistry and Physics 78(2): 480-485.

Ma, J. \& Lim, L.C. 2002. Effect of particle size distribution on sintering of agglomerate-free submicron alumina powder compacts. Journal of the European Ceramic Society 22(13): 2197-2208.

Muchtar, A. \& Lim, L.C. 1998. Indentation fracture toughness of high purity submicron alumina. Acta Materialia 46(5): 1683-1690.

Ozturk, O., Uludag, B., Usumez, A., Sahin, V. \& Celik, G. 2008. The effect of ceramic thickness and number of firings on the color of two all-ceramic systems. The Journal of Prosthetic Dentistry 100(2): 99-106.

Rafferty, A., Alsebaie, A.M., Olabi, A.G. \& Prescott, T. 2009. Properties of zirconia-toughened-alumina prepared via powder processing and colloidal processing routes. Journal of Colloid and Interface Science 329(2): 310-315.

Rami, M.L., Meireles, M., Cabane, B. \& Guizard, C. 2009. Colloidal stability for concentrated zirconia aqueous suspensions. Journal of the American Ceramic Society 92: 50-56.

Stawarczyk, B., Özcan, M., Hallmann, L., Ender, A., Mehl, A. \& Hämmerlet, C.F. 2012. The effect of zirconia sintering temperature on flexural strength, grain size, and contrast ratio. Clinical Oral Investigations 17(1): 1-6.
Sulaiman, T.A., Abdulmajeed, A.A., Donovan, T.E., Ritter, A.V., Vallittu, P.K., Närhi, T.O. \& Lassila, L.V. 2015. Optical properties and light irradiance of monolithic zirconia at variable thicknesses. Dental Materials 31(10): 1180-1187.

Ting, J.M. \& Lin, R.Y. 1995. Effect of particle size distribution on sintering. Journal of Materials Science 30(9): 2382-2389.

Tong, H., Tanaka, C.B., Kaizer, M.R. \& Zhang, Y. 2016. Characterization of three commercial Y-TZP ceramics produced for their high-translucency, high-strength and high-surface area. Ceramics International 42(1, Part B): 1077-1085

Trunec, M. \& Pouchly, V. 2016. Colloidal processing of low-concentrated zirconia nanosuspension using osmotic consolidation. Ceramics International 42(10): 11838-11843.

Wollmershauser, J.A., Feigelson, B.N., Gorzkowski, E.P., Ellis, C.T., Goswami, R., Qadri, S.B., Tischler, J.G., Kub, F.J. \& Everett, R.K. 2014. An extended hardness limit in bulk nanoceramics. Acta Materialia 69: 9-16.

Xie, Z., Ma, J., Xu, Q., Huang, Y. \& Cheng, Y.B. 2004. Effects of dispersants and soluble counter-ions on aqueous dispersibility of nano-sized zirconia powder. Ceramics International 30(2): 219-224.

Zakaria, H., Muhamad, N., Sulong, A.B., Ibrahim, M.H.I. \& Foudzi, F. 2014. Moldability characteristics of $3 \mathrm{~mol} \%$ yttria stabilized zirconia feedstock for micro-powder injection molding process. Sains Malaysiana 43(1): 129-136.

Zhang, H., Li, Z., Kim, B.N., Morita, K., Yoshida, H., Hiraga, K \& Sakka, Y. 2012. Effect of alumina dopant on transparency of tetragonal zirconia. Journal of Nanomaterials 2012: 5.

Zhang, Y. 2014. Making yttria-stabilized tetragonal zirconia translucent. Dental Materials 30(10): 1195-1203.

Chuin Hao Chin, Andanastuti Muchtar*, Che Husna Azhari \& Mohamed Aboras

Department of Mechanical and Materials Engineering

Faculty of Engineering and Built Environment

Universiti Kebangsaan Malaysia

43600 UKM Bangi, Selangor Darul Ehsan

Malaysia

Masfueh Razali

Periodontology Department

Faculty of Dentistry

Universiti Kebangsaan Malaysia

Jalan Raja Muda Abdul Aziz

50300 Kuala Lumpur, Federal Territory

Malaysia

*Corresponding author; email: muchtar@ukm.edu.my

Received: 14 December 2017

Accepted: 23 February 2018 